\title{
Ethnobotany of sugar palm (Arenga pinnata) in the Sasak Community, Kekait Village, West Nusa Tenggara, Indonesia
}

\author{
ANGGIT HARYOSO ${ }^{1, \bullet}$, ERVIZAL A.M. ZUHUD ${ }^{1, \bullet \bullet}$, AGUS HIKMAT ${ }^{1}$, ARZYANA SUNKAR ${ }^{1}$, \\ DUDUNG DARUSMAN ${ }^{2}$ \\ ${ }^{1}$ Department of Forest Resources Conservation and Ecotourism, Faculty of Forestry, Institut Pertanian Bogor. J1. Lingkar Akademik, Dramaga Campus, \\ Bogor 16680, West Java, Indonesia. Tel.: +62-251-8621947`email: masanggite@yahoo.com; ^^ervizal_amzu @yahoo.com \\ ${ }^{2}$ Department of Forest Management, Faculty of Forestry, Institut Pertanian Bogor. J1. Lingkar Akademik, Dramaga Campus, Bogor 16680, West Java, \\ Indonesia
}

Manuscript received: 30 September 2019. Revision accepted: 10 December 2019.

\begin{abstract}
Haryoso A, Zuhud EAM, Hikmat A, Sunkar A, Darusman D. 2020. Ethnobotany of sugar palm (Arenga pinnata) in the Sasak Community, Kekait Village, West Nusa Tenggara, Indonesia. Biodiversitas 21: 117-128. Sugar palm (Arenga pinnata Merr.) is one kind of palm that has high potential ecological, economic, and socio-cultural values. This Research aimed to identify the ethnobotanical aspects of sugar palm, especially on aspects related to farmers characteristics, cultivation, utilization, cooking process of palm sugar sap and sugar palm marketing at the Kekait Village, West Lombok District, West Nusa Tenggara Province. Data were collected using participatory observation, in-depth interviews, literature studies, and the selection of informants conducted by purposive sampling. Sugar palm farmers were adult men aged between 42 to 63 years old. They achieved life skills provision from parents to their children. The characteristics of sugar palm farmers in the Sasak community are adult men to the elderly, aged 24-63 years. The source of knowledge about the use of sugar palm is hereditary from parents (father or grandfather). Oil palm farmers in the Sasak community in Kekait Village do not carry out intensive cultivation systems, they still rely on natural services, both regeneration and distribution. The most widely used part of the palm tree is tassel $(76.32 \%)$, to be tapped. Processing palm sugar into sugar is still carried out with traditional methods and tools, as well as natural ingredients. Sugar palm farmers in Kekait Village were very dependent on small collectors who sell their sugar products. Farmers are in the weakest position in the marketing chains and did not have a bargaining position to determine the price of palm sugar.
\end{abstract}

Keywords: Lombok island, natural sweetener, Sasak tribe, subsistence, tuak

\section{INTRODUCTION}

Sugar palm is a plant with multiple benefits that could be found in several countries in the world, particularly in the region of Tropical Asia $\left(20^{\circ} \mathrm{NL}-11^{\circ} \mathrm{SL}\right)$ countries. Dransfild et al. (2014) stated about 20 ranging from India, South China, Ryukyus and Taiwan, through Southeast Asia, Malesia including Christmas Island (Indian Ocean) to north Australia, the greatest diversity occurring on the Sunda shelf. It is an endemic plant in Southeast Asian countries. Sugar palm is well distributed in Indonesia. It can be found in almost the Indonesia archipelago. Ministry of Agriculture data (2013) mentioned that sugar palm was well distributed in Indonesia and could be easily found in 14 provinces, included: Papua, Maluku, North Maluku, North Sulawesi, South Sulawesi, Southeast Sulawesi, Central Java, West Java, Banten, South Kalimantan, West Sumatra, North Sumatra, Bengkulu, and Nangroe Aceh Darussalam, within covers of a total area of \pm 70000 hectares.

Indonesia has 1340 ethnicities (BPS-Statistics Indonesia, 2010). Each of these ethnicities groups has a unique use of sugar palm plants in their daily activities. Approximately 150 local names of sugar palm can be found in the territory of Indonesia from Sabang to Merauke reflected that sugar palm is familiar with Indonesian households and multipurpose plants (Zuhud et al. 2014; Kurniawan et al. 2018). According to Anderson et al. (2011), each ethnic group has different perceptions, concepts, management and ways of using sugar palms. Among those ethnicities is Sasak Tribe who lives on Lombok Island. The Sasak Tribe has had economical, ecological, and socio-cultural bound in utilizing sugar palm plants, especially those who lived in Kekait Village, Gunungsari Subdistrict, West Lombok District, West Nusa Tenggara Province. In fact, ties have been firmly established before the area was designated as a village in 1866 (Profile of Kekait village 2017) until nowadays. Sukenti et al. (2016) mentioned that Kekait Village is the best brown sugar producer village in West Lombok District.

Furthermore, they bonded in the identity of the village, as "Aren Village," a village with the potential of the natural resources typical of palm trees and the spirit of life of the people who are "Agrarian, Religious, Educative, Naturalist" (AREN). The bounding between sugar palm and the villagers has become the indicator that sugar palm has been utilized by the Sasak Tribe community in Kekait Village for a long time. However, until now the relationship between the Sasak people in the Kekait Village and palm trees has not been well documented. Nonetheless, losing local knowledge on how to utilized plants has 
continued to increase over time. Therefore, this research is fundamental to conduct.

The research aimed to identify identifies the ethnobotanical aspects of sugar palm, especially on aspects related to farmers characteristics, cultivation, utilization, cooking process of palm sugar sap and palm sugar marketing at the Kekait Village, West Lombok District, West Nusa Tenggara Province, Indonesia.

\section{MATERIALS AND METHODS}

\section{Study area}

The study was conducted in Kekait Village, Gunungsari Subdistrict, West Lombok District, West Nusa Tenggara Province, Indonesia. Kekait Village area is directly adjacent to Pemenang Barat Village, Pemenang Subdistrict, North Lombok District in the North, Taman Sari Village in the East, Gunungsari Village in the South, and Pusuk Lestari Village and Lembah Sari Village in Batulayar Subdistrict off the West. The village of Kekait has a slightly wet climate or Type $\mathrm{C}$ in the Schmidt-Ferguson Climate type classification system. Located at an altitude of 5-650 $\mathrm{m}$ above sea level, this village has a hilly topography with $5-40 \%$ slope (Figure 1).

\section{Procedures}

The types and sources of primary and secondary data related to the ethnobotany of sugar palm and the characteristics of sugar palm farmers were collected using participatory observation, in-depth interviews, and documentation (Cotton 1996; Cunningham 2001; Djamal 2015). In participatory observation, researchers are directly involved in the activities of the research object. Information gathering was carried out by openly interviewing 9 key informants and 110 informants, which were purposively selected. Documentation is done by directly using photos and videos, and indirectly by reviewing government documents or related agencies.

\section{Data analysis}

Ethnobotany data analysis of sugar palm and the characteristics of sugar palm farmers were carried out by emical and ethical approaches. Emic approach (knowledge) is arranging patterns of community idea into a system through a list of standard questions obtained through interviews with resource persons. At this stage, a list of all types of local benefits of palm sugar is provided by the resource person (emic). The second approach is the ethical approach (science), which is synthesizing (uniting) various theories into a theoretical research framework. Further beneficial comparison from both approaches was carried out. From this comparison, the confrontation analysis was held to obtain some point of view between community knowledge and modern knowledge (qualitative analysis) (Cotton 1996; Cunningham 2001; Djamal 2015).

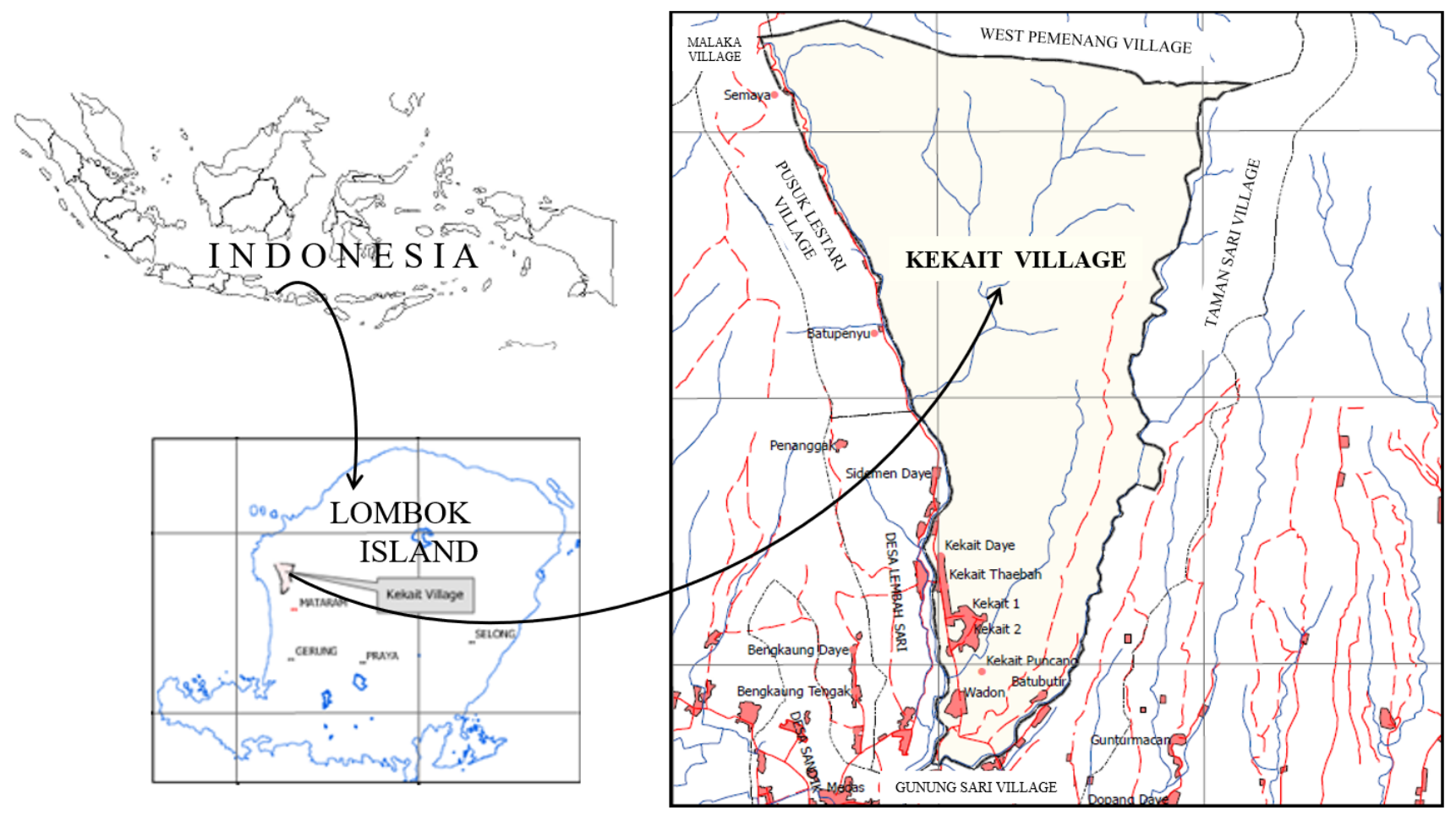

Figure 1. Research location at Kekait Village, Gunungsari Subdistrict, West Lombok District, West Nusa Tenggara Province, Indonesia $\left(8^{\circ} 28^{\prime} 30^{\prime \prime}-8^{\circ} 31^{\prime} 30^{\prime \prime} \mathrm{S}\right.$, and $116^{\circ} 4^{\prime} 30^{\prime \prime}-116^{\circ} 70^{\prime}$ ” E) 


\section{RESULTS AND DISCUSSION}

\section{Farmers characteristics \\ Gender}

The observation at the study site found 119 male sugar palm farmers (100\%). The male farmers domination in aren farming activities was not based on a robust patriarchal system that applies to the Sasak Tribe community, but based on physical demands and time sacrifices of a sugar palm farmer, especially during the process of tapping and cooking palm sap in the Kekait Village. The hard activities that must be carried out by a sugar palm farmer, especially for harvesting sap and other parts caused the women's role has become marginalized. The dealing patterns between men (husbands) and women (wives) roles in the farmer families are inseparable regarding the palm sugar management and exploitation in daily routinely. The same thing was found by Hapsari et al. (2017) in six districts in East Java the majority of men were found working in agriculture during the day, while women were at home. Puspitawati et al. (2018) state that in general, gender roles in agricultural activities, in terms of access and control of agricultural resources, are dominated by men. Role differentiation is a structural prerequisite for family survival. If women must continue to be involved in aren farming (yield utilization) which requires continued presence and time, it will create a family imbalance that can lead to the achievement of wrong family goals (Puspitawati et al. 2018).

\section{Age structure}

Age distribution of sugar palm farmers in Kekait Village was ranged from 28 to 67 years old. Based on the developmental age classification determined by the Ministry of Health (2009), the farmers categorized as early adult groups occupied $0.84 \%$ of sample, $26.05 \%$ late adult, $42.86 \%$ early elderly, $29.41 \%$ late elderly, and $0.84 \%$ old age. The majority of sugar palm farmers were in the early and late elderly groups. The same opinion was conveyed by Widayati et al. (2018) that sugar palm farmers in Muna, Southeast Sulawesi Province are in productive age (42 years). The results indicated that the younger generation in Kekait Village is no longer interested to succeed sugar palm farmers as livelihood sources. Hence this condition continues, the existence of sugar palm farmers in Kekait Village would only become a story in the future, and the extinction of the sugar palm farmers would mean the loss of local knowledge on how utilizing sugar palm.

The lack of interest of the younger generation to succeed palm farmers generally could be due to: internal (farm family) and external (surrounding communities/ coeval, education, government, and technological developments) factors. There could be two causes of why young people do not want to be a sugar palm farmer, firstly: young people assume that dirty sugar palm farmer is not a profession to be proud of. Secondly, most parents (sugar palm farmers) wish their children to get better jobs by sending them to schools as high as possible.

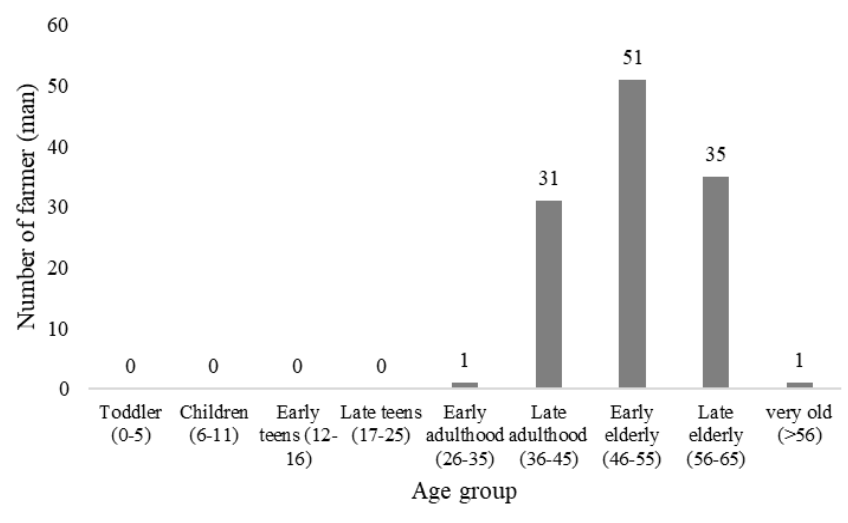

Figure 2. Sugar palm farmers age group distribution

While external factors could be due to the coeval lifestyles in the surrounding environment who works as Indonesian labor migrants (TKI), education system that was not based on local knowledge, the influence of technological developments increasingly alienates the younger generation in its culture, and the lack of government support to the welfare of sugar palm farmers. All of the above factors could discourage young generation to be sugar palm farmers. Parrota et al. (2009) suggested that the ethnobotany knowledge and local practices related to plant resource management are rapidly disappearing due to various factors, such as globalization, infrastructure development, agricultural innovation, tourism development, market interventions, and government policies and regulations. Those factors had impacted the declining concern of traditional wisdom, local knowledge, and lifestyle of young generation. In Kiding Village of Malaysia, the population of nyok or aren plants was threatened by the younger generations which have lost their interest to maintain aren's sustainability. The knowledge about palm sugar processing is decreased even though the older generation are still planting and preserving it in their area (Lee 2015). These problems are similar to those reported by Hidayati (2017) research in the Baduy community of Banten Province which showed a decline in the level of their local knowledge of plants. Both Lee and Hidayati results indicated that local knowledge is gradually decreased in the inheritance of knowledge to the younger generation.

\section{Source of knowledge}

Selapuk penyadep nao dengan mame, laguk ndek selapuk dengan mame tao kance mampu jari penyadep, means that the sugar palm farmers are male, but not all men could become sugar palm farmers, this statement was told by Haji Zaini as the head of Kekait Village. The skill to tap palm sugar is a life skill that should be mastered by boys as a provision for their lives in the future. The boys get the skills hereditary from their parents (father or grandfather) as well as their individual experiences of trial and error processes (Ellen 2006). Hernanto (1989) stated that farming and cultivation of crops and livestock became a culture that was handed down hereditary. Abdullah et al. 
(2014); Tamrin et al. (2015); Febriyanti et al. (2017); Gunawan et al. (2018); Withaningsih et al. (2019); suggested that the source of knowledge possessed by palm sugar craftsmen is mostly obtained from parents and they have learned basic skills in business for a long time. The observations results showed a tendency of reducing sugar palm farmers alongside with increasing levels of education. Most of the sugar palm farmers in Kekait Village were lack of higher education background. The higher the educational background of a man, the lower his motivation for working as a farmer as his main livelihood. The interview results showed that out of 114 sugar palm farmers expressed their opinion that knowledge about sugar palm was obtained hereditary, $75.43 \%$ of whom got their knowledge directly from parents, especially fathers and grandfathers, while the remaining of $24.57 \%$ gained their knowledge by self-study. The process passing of the skill started at the age of 7-8 years old where parents (father or grandfather) had introduced palm trees to their children or grandchildren by taking them to the garden every day.

At the age of 11-12 years old, children or grandchildren were given the task of selling palm sugar to the market or collectors in the village. Later, as the child grew older, he would be taught with tapping skills such as (climbing, cleaning the stem, hitting and rocking flower bunches, and slicing flower bunches) by his parents. Finally, they would learn how to processing sap became sugar palm. Unmarried boys who still live with their parents have an obligation to help their parents farm in the garden. The obligation will be lost where the boy is married and lives separately from his parents. Thus, the knowledge transfer of how to manage and utilize sugar palm from parents to children is a valuable capital for children who consider married and separated from his parents. Mead (1975) as mentioned in Matsumoto and Juang (2004) argued that parenting is an essential way of channeling culture hereditary. Similar things mentioned by Meinarno et al. (2011) that the process of knowledge transfer and culture could be seen in the activities of parents inviting their children to work or going to worship place. In this activity, culture and knowledge are transmitted gradually from the older generation to the younger generation for a long time. The observations results at the study site showed that palm farmers in Kekait Village are currently second generation, third generation, and fourth generation. These results proved that the inheritance of aren knowledge passed down hereditary

\section{Livelihood}

The most occupied livelihood of the Kekait Village community is farmers, either owned farmers, sharecroppers or farm laborers. There are only small amount occupied as entrepreneurs, teachers, and day laborers. Based on the cultivated land, farmers in Kekait Village could be divided into two professions, which are: dryland farmers and rice farmers (irrigation). The rice farmers dominate dryland farmers. The domination can be seen from the comparison of both land area, 909 hectares of dry land area, and only 17 hectares of wetland area (2017 Kekait Village RPJM). Most dryland farmers are garden farmers, who rely on fulfilling their daily needs from the sap produced by sugar palm trees.

Being a sugar palm farmer, someone must be diligent and disciplined because if the palm tree is ready to be tapped, the farmer should process it every day even in adverse weather conditions (rain, earthquake). Sugar palm farmers rarely have multiple professions since the garden location is far for their home $(0.5-6 \mathrm{~km})$, and it needs a routine and continuity to process palm sugar every day. Palm farmers find that it is difficult to manage their time into other professions, such as rice farmers, raising livestock, or trading due to the sugar palm processing activity. In one trip it takes 45 minutes-3 hours from their home to the garden on foot, then harvesting the sap while installing a new sapper in several palm trees (15-30 minutes), the morning and evening (07.00 WITA and 16.00 WITA). Moreover, the sap water should be cooked and poured into mold for 3-4 hours. The length of travel time and the process of taking and cooking palm sugar demands the palm farmers in Kekait Village concentrate only onto single profession. On the contrary, Febriyanti et al. (2017) mentioned that palm farmers in the Sundanese Tribe community of Kasepuhan Pasir Eurih in Sindanglaya Village carried out tapping activities of palm sap after paddy farming or cattle breeding was completed. This is because of the palm garden location situated nearby with the residence (one compact unit).

\section{Landowner}

The data collection showed that the majority of sugar palm farmers in Kekait Village used aren in their gardens or owned by farmers (gawah). Similar condition was mentioned by Tamrin et al. (2015) in South Halmahera, he acknowledges cultivated land by sugar palm farmers is a land that is simply managed, in addition. In addition, Febriyanti et al. (2017) at the Kasepuhan Pasir Eurih community stated that the sugar palm trees utilized by farmers are sugar palm trees in the garden (talun) that belonged to the population. Likewise in Karwa, India, palms such as areca nut and coconut are found in community gardens (Baht et al. 2014). Although the majority of sugar palm farmers are owned farmers, however, they only have 0.4-0.5 hectares each of them. Sajogyo (1977) as mentioned in Susilowati and Maulana (2012) stated that farmers with a land area of less than 0.5 ha are included in the category of small-scale farmers. Some farmers said that in the time their parents were still alive, the area of the garden ranged from 2-3 ha. However, after the parents die, the garden area was shared with their children following the inheritance law that applies to Islam. Thus, it is common that at present the majority of sugar palm farmers are small-scale farmers.

Hernanto (1989) mentioned that the agricultural sector carries a heavy burden of problems caused by the clamping of farmland due to the distribution of inheritance reasons. Additionally, neither the dynamics of changes in land ownership nor sale and purchase of land occurred rapidly. The changes of landowners mainly reflected in the phenomenon of mortgaging gardens to obtain capital to become migrant labors abroad, either for themselves or their children. Therefore, if someone has a garden area with 
an area of more than 1 hectares in one place, then the farmer categorized as sufficient farmer. Land ownership for the Sasak Tribe community in Kekait Village shows both economy ability and social status. Hernanto (1989) emphasized that a community member who controls and/or has a production factor could provide a high position or social status in his environment.

Based on the ownership status of the plantation land, sugar palm farmers in Kekait Village could be classified into two types, which are: farmer and peasant/ sharecroppers. Owned farmers are sugar palm farmers performed in tapping palm trees in their own gardens, while sharecroppers or commonly called "penyakap" are Sugar palm farmers whose tapping activities are carried out on other people's land. Sharecroppers do this for several reasons as follows: (i) The owned garden has a massive size (more than ten trees) that the owners needed a help form "penyakap" to tap the sap water; (ii) Garden owner deceased, while there are no descendants could follow their ancestors become a palm sugar farmers; (iii) Garden owner has a severe illness, so they could not be harvesting sap water any longer. Thus, the quality of sap water decrease or damage due to fermented processing; (iv) The aging garden owner could not afford to harvest any, at the same time there are no younger generation of farmers could continue tapping palm sugar palm in their garden; (v) Garden owner become migrant workers abroad, while the younger generation could not continue to tap palm sugar palm in their garden.

The relationship between the penyakap and the owner of the garden is based on mutual trust by both parties. Therefore the system which commonly used for the harvesting palm sugar is profit sharing. Profit-sharing methods used in the systems by dividing the tapping yield alternately. It is divided once or in a two days interval considering the volume of yield. The yield should be fulfilled the minimum amount of molded sugar to be sold (generally they sold ten molded-sugar). Hence the minimum amount of molded sugar could be fulfilled in a day; then it is called "daily profit sharing," hereafter if the minimum amount of molded sugar could be fulfilled in 2 days then it is called "alternate profit-sharing." During this research, the commonly used profit-sharing system was a lapse of one day, while the daily system was rarely found. The payment from the molded sugar sales received by the penyakap did not be deposited every day or intervals day, but two weeks or once a month to the garden owner.

\section{Ethnobotanical aspect of Arenga pinnata \\ Cultivation system}

Sugar palm in the Kekait Village cultivated naturally by the farmers within a less human intervention. This condition could be seen from the spacing distance among the sugar palm trees which are not uniform. Besides, the number of palm sugar saplings clustered around the main trees. Palm farmers would do thinning if only the survived juveniles are clumps very densely. For example, there is 6 clustered juveniles sugar palm, and then the farmers would reduce two juveniles sugar palm. The undertaken action was to provide sufficient space for the development of other four juveniles. The selected juvenile is considered the worst which has physical conditions as mentioned: growth slowly, fewer midribs, and leaf midribs more rigid when compared to others that are close together. Murtado et al. (2014) mentioned there are not many people have cultivated sugar palm plants because large-scale propagation technology has not been mastered until nowadays. Moreover, research on post-harvest technology and preservation of palm sap is still lacking, and business management is also still weak. Related to this statement, Lempang (2012); Yuldiati et al. (2016); Surya et al. (2018) stated that the demand for products whose raw materials from palm trees so far have been fulfilled from wild palm trees.

Most sugar palm farmers believe that some saplings lived farther from the main trees are distributed by animals help, such as "ujat" or Rinjani Weasel (Paradoxurus hermaphroditus rindjanicus). Similiar condition applied in the Cipanggulan community, Cianjur District. Although palm trees provide benefits for some people, nonetheless the community does not carry out intensive cultivation. Hence palm trees could be found in various places because of the civet or palm civet's (Paradoxurus hermaphroditus pallas) help (Gunawan et al. 2018). Campbell et al. (2008) revealed that complex hormone interactions produced edible fruit and lured the animals to spread the seeds. The ripe palm sugar eaten by civet would be digested through the digestive process (Iskandar et al. 2016; Partasasmita et al. 2016). However, the sugar palm seeds in it will not be digested and released along with the feces (endozoochory). Palm farmers believe that sugar palm seeds that came out from ujat's feces would become growth faster seeds, compared to palm seeds that are naturally embedded around the main trees. In consequence, the Kekait Village community, particularly sugar palm farmers prohibit ujat's hunting. As a result of relying on natural regeneration, there was lack of stapped palm trees at a specific time which generally called famine time.

\section{The utilized part of palm tree}

The Sasak Tribe community in Kekait Village places palm trees in a unique position as a "gift" tree or blessing tree. Palm trees are a gift from Allah Subhanahu wa Ta'ala (God) with many benefits that could not be compared to other types of trees. All parts of the palm tree including roots, stems (deep or pith, outside or peripheral), leaves (young and old), fruits, and flowers could be utilized (Table 1). Gunawan et al. (2018) mentioned the same thing in the Cipanggulan community, Cianjur District, West Java Province that sugar palm is a vital plant compared to other types of plants, all parts of sugar palm plants could be utilized from roots, stems, fibers, leaves, fruits, and flowers. Although all parts of the palm tree could be utilized, not all parts could be used simultaneously. To be able to use the sugar palm, farmers in Kekait Village naturally have two choices to utilize: cutting down or not cutting down the palm trees. Should they choose to cut down the trees, the parts of the tree that could be utilized economically are the stems for making sago flour and palm fiber. The cutting down trees is one time only harvesting during the life cycle and sugar palm trees perished. 
Table 1. the utilized part of sugar palm

\begin{tabular}{llc}
\hline Parts & Utilization & $\begin{array}{c}\text { Percentage of part } \\
\text { being utilized (\%) }\end{array}$ \\
\hline Root & As a traditional medicine to cure bladder disease, urinoir infection, and arthritic & 0.88 \\
Inner stem & As sago flour ingredients, while the dregs are utilized for mushroom backlogs & 3.51 \\
Outer stem & As a gutter, hoe handles, cooking and household utensils, and firewood & 2.63 \\
Leaf midrib & As an ingredient in making kodong or fish trap & 0.88 \\
midvein & As primary material in making broomsticks and plates & 0.88 \\
Young leaves & As a tobacco wrapper (traditional cigarette) & 1.75 \\
Old leaves & As a traditional food wrapping material, ornaments of traditional events & 0.88 \\
Flowers bunch & As a leading source for making palm sugar, fresh sap water both as a cure for diabetes & $\mathbf{7 6 . 3 2}$ \\
& and sprue, fresh flowers for animal feed and dried panicles are used as crafts & 6.14 \\
Fruits & As a source of healthy food, commonly referred to as kolang-kaling or bêluluk by the & \\
& Sasak people, the remaining skin of fruit is used as animal feed & 6.14 \\
Palm fiber & As a material for traditional building roofs, palm brooms, absorbing household waste, & \\
& reinforcing water dams, and traditional house ornaments known as gelengan & \\
\hline
\end{tabular}

Conversely, if the trees do not cut down, the parts of the tree that could be utilized economically are palm sugar from flowers, kolang kaling from fruit, and palm fiber (ijuk). The use of palm sugar from flowers could be done several times periodically in 1 life cycle of palm trees, one flower bunch can be tapped 3-4 months every day (morning and evening), and the palm regeneration process could be adequately maintained because the farmers in Kekait Village always leave 1-2 fruit bunches to obtain kolang kaling. In this case, the majority of sugar palm farmers in Kekait Village prefer the second method of utilization which is not cutting down palm trees. This means that the local wisdom activities of utilizing sugar palm trees wisely could guarantee the fulfillment of life needs sustainably.

The majority of sugar palm farmers in Kekait Village have chosen sap water to be processed into palm sugar or commonly called cupak sugar. The word "cupak" is taken from the name of a molder from bamboo made to mold sugar palm and known as cupak by the community. Lempang (2012) stated that molded sugars generally have the shape according to the shape of the mold being used. Palm sugar has a unique position in the culture and daily life of the Sasak Tribe community. For example in the elopement (adat kawin lari) in the Sasak community or mêrariq, palm sugar becomes a "breaker" at the sorong serah ceremony, which is one part of the tradition of elopement which most determined the validity of marriage. If all the ajikrama (traditional bailing) has been calculated and there is no shortage at all, all the items will be lifted onto the berugak, place of the ceremony. Then a Kyai (Islam's religious leader) took the brown sugar that was tucked among the ajikrama, then it would be broken down into small pieces and shared it with all those present to eat, as a sign of the agreement of all community leaders and religious leaders to the marriage. Yasin (2008) implied mêrariq is a genuine local culture and ritual from the Sasak community ancestor which still exists nowadays.

Palm sugar also has essential position for the community as a sweetener for traditional foods and drinks of Sasak Tribe, such as kêraké, gulasari, pumpkin tumbêk, palm coffee, and, sherbet. Sukenti et al. (2016) pointed out that A. pinnata Merr. included in 10 species of plants that are widely used by the Sasak people. It is used for daily life, traditional, and religious ceremonies as food and beverage sweeteners. The high utilization of sap becomes palm sugar is inseparable from the religious background of the majority Kekait Village community, which is Islam religion that prohibits drinking alcoholic beverages (tuak). Unlike the Batang Toru community in North Sumatra, palm sugar is mostly processed into tuak, because the majority of the people have Christianity backgrounds who do not prohibit drinking alcoholic beverages such as palm wine (Martini et al. 2012).

\section{Palm sugar sapping process}

Palm sugar farmers in Kekait Village have been implementing stages in tapping sap from flower bunches (pêji) so that they could be tapped for generations. As Tamrin et al. (2015) in South Halmahera, and Febriyanti et al. (2017) in Banten, the molding processes of sugar palm is done with simple equipment, such as bamboo, cauldron or pan, clay furnace. While Gunawan et al. (2018) mention several stages of harvesting palm sugar in Cipanggulan community, Cianjur District from climbing aren trees using bamboo ladders, cleaning leaf midribs, hitting and swinging bunches, and tapping palm sugar palm juice. The stages of tapping palm sugar in the Sasak community in Kekait Village, West Nusa Tenggara are as follows:

First process. Sap water processing would be done as soon as possible after the sap scent from the flower fissured. The typical scent from the palm sugar known as mambu angin or bou angin by the farmers. Local sugar palm farmers interpret the scent as a distinctive aroma of palm sugar which begins to burst and then carried out by the wind until sugar palm farmers faintly smell it.

Second process. In addition to the bursting flower, the farmers would ensure that some flowers have begun to fissure. After capturing the signal, the farmers made several preparations. The preparations are making a ladder (sanggéng) made from bamboo stick or tréng galah (Gigantochloa atter) as a tool for farmers to climb palm 
trees; cleaning out the midribs leaf; cleaning out the fibers (njuk) which cover the stem using parang timpas (batéq timpas); cleaning the flower bunches from the flower petals (seludang) and tie it to the tree above to avoid broken flower bunches. Tying the flower bunches is important because the flower panicle's weight would increase every day, broken bunches could not produce sap water when it sliced (pêsuk). Cleaning midribs steam activities from the midribs palm fibers and flower petals are called ngélah (Figure 3.A).

Third process. After 2-3 days of mambu angin (no. 1), sugar palm farmers will hit (mantokin) and shake (bêgéyong) flower bunches (Figures 3.B-C). Kurniawan et al. 2018) stated knocking neera is an important step because neera tends to degrade immediately and cause poor quality palm sugar. The circumstances of hitting and shaking the bunch of flowers called the bakêt. Beating is carried out evenly throughout the flower bunches, from the base attached to the stem to the border of the flower pan. Based on the observations, farmers hit the flower bunch for \pm 10 minutes with total hit for nearly \pm 200 times. While shaking the bunch of flowers as much as \pm 40 times in one series (1 bakêt). As an illustration, the amount of bakêt in flower bunches can be seen in Table 2. Based on the experience of sugar palm farmers who have been harvesting for decades, the number hitting and shaking the flower bunches or bakêt depends on the flower bunch be tapped. Generally, the first arenaceous flowers (puniq) get more bakêt than the second or so on appearance (langkék). The first palm flower is 6 bakêt (50 days), while the second palm flower and so on are fewer, only 4 bakêt (34 days).

Fourth process. After completing 3 stages of tapping preparation, the farmer would cut the palm flower bunches using special machetes. Parang (machete) has a sharp side and a very thin blade that resembles the "S" letter, commonly called sadep. Farmers would cut the palm flower right at the top of the flower panicle (Figure 3.D). Based on the interview, some palm farmers usually had a dream of flood at the night before the cutting process is held, as a sign that the flower bunch would be diligently dripping (pacu). After cutting the flower bunch, the farmer then would thinly slice the ends of the flower bunches (1520 slices) until the dripping is smooth (bongar), then at the ends of the slice are cleaned up using hand palms and clean water (pêrêsik). The next step is to install the palm sugar container in the form of clay pots (bongs), bamboo (bumbung), or jerry cans. However, before putting the sap water into the container, the farmers would add a natural preservative into the sap water.

The natural preservatives of sap water are in a wood form (stems or roots) or leaves of certain tree species that farmers get knowledge hereditary. The farmer refers to the natural preservatives as pakêt. The same opinion was expressed by Withaningsih et al. (2019), that the farmers in Sukaresmi, West Bandung gained knowledge about palm sugar management through independent learning The observation results revealed that there were four species of plants used as pakêt, namely: purut wood (Dysoxylum parasiticum Osbeck.), badung wood (Garcinia parvifolia (Miq.) Miq.), mundah leaves (Garcinia dulcis (Roxb.) Kurz.), and bintangur leaves (Callophylum soulatri Burm. f.). Palm sugar farmers in Kekait Village mostly use purut wood (Dysoxylum parasiticum Osbeck.) as the main choice of pakêt. Sugar palm farmers use their instincts and experiences in determining the right size of pakêt to be put into a palm sugar container by paying attention to the previous results of sapper reservoir.

Table 2. The amount of bakêt treated to flower bunch

\begin{tabular}{|c|c|c|c|}
\hline $\begin{array}{l}\text { Bakêt } \\
\text { (series) }\end{array}$ & $\begin{array}{c}\text { Period } \\
\text { days }\end{array}$ & Treatment to flower bunch & Type of bunch \\
\hline \multirow[t]{2}{*}{$\begin{array}{l}\text { First } \\
(\text { Sekék) }\end{array}$} & 3 & $\begin{array}{l}\text { Beating is carried out evenly throughout the flower bunches, from the base attached to } \\
\text { the stem to the border of the flower pan. The flower shook once in a day for three days } \\
\text { consecutively }\end{array}$ & $\begin{array}{l}\text { First flower, second } \\
\text { flower, etc. }\end{array}$ \\
\hline & 7 & Break & \\
\hline \multirow[t]{2}{*}{$\begin{array}{l}\text { Second } \\
(D u \hat{e})\end{array}$} & 1 & $\begin{array}{l}\text { Beating is carried out evenly throughout the flower bunches, from the base attached to } \\
\text { the stem to the border of the flower pan. The flower shook once in a day }\end{array}$ & $\begin{array}{l}\text { First flower, second } \\
\text { flower, etc. }\end{array}$ \\
\hline & 7 & Break & \\
\hline \multirow[t]{2}{*}{$\begin{array}{l}\text { Third } \\
\text { (Têlu) }\end{array}$} & 1 & $\begin{array}{l}\text { Beating is carried out evenly throughout the flower bunches, from the base attached to } \\
\text { the stem to the border of the flower pan. The flower shook once in a day }\end{array}$ & $\begin{array}{l}\text { First flower, second } \\
\text { flower, etc. }\end{array}$ \\
\hline & 7 & Break & \\
\hline \multirow[t]{2}{*}{$\begin{array}{l}\text { Fourth } \\
\text { (Mpat) }\end{array}$} & 1 & $\begin{array}{l}\text { Beating is carried out evenly throughout the flower bunches, from the base attached to } \\
\text { the stem to the border of the flower pan. The flower shooked once in a day }\end{array}$ & First flower \\
\hline & 7 & Break & \\
\hline \multirow[t]{2}{*}{$\begin{array}{l}\text { Fifth } \\
(\text { Limê })\end{array}$} & 1 & $\begin{array}{l}\text { Beating is carried out evenly throughout the flower bunches, from the base attached to } \\
\text { the stem to the border of the flower pan. The flower shooked once in a day }\end{array}$ & First flower \\
\hline & 7 & Break & \\
\hline \multirow[t]{2}{*}{$\begin{array}{l}\text { Sixth } \\
(N e ̂ m)\end{array}$} & 1 & $\begin{array}{l}\text { Beating is carried out evenly throughout the flower bunches, from the base attached to } \\
\text { the stem to the border of the flower pan. The flower shooked once in a day }\end{array}$ & - \\
\hline & 7 & Break & \\
\hline
\end{tabular}


As the benchmark, the purut wood used to preserve 51 palm sugar are as the amount size of adult hands. Astuti (2018) stated that the addition of $1 \%$ of purut wood from the weight of palm sap, is able to maintain the quality of sugar palm for 24 hours. It turns out that the use of purut wood could prevent the growth of Saccharomyces cerevisiae in damaging the freshness of the sap water. Rumokoi (1990) in Lempang (2012) mentioned that the dominant microorganisms in the sap fermentation are Saccharomyces cerevisiae, in addition to other yeast types, such as Schizosaccharomyces sp. and Candida sp.

Fifth process. Farmers would pick up the results of tapping as well as installed new sap water container twice a day in the morning (06.00-07.00 WITA) and in the afternoon (15.00-16.00 WITA) (Figure 3.E). During the sap water harvesting process (3-4 months) the farmers must be in an ethical and clean mood, must not commit disgraceful deeds, and must not fight with their wives. If the farmers are in a depressed mood, they believed that the palm tree would get angry and would stop dripping. This means that sugar palm farmers must be diligent, disciplined, and focused on the tapping process, so that the palm juice that comes out of the flower bunches is in line with expectations, smooth and plenty. The sap water that has been picked up from storage has to be cooked immediately because if it is left too long, the sap water would quickly become acidic. Since the sap water too acidic or damaged the ap water could not be molded even though the sap water had been cooked for a long time. Ain et al. (2014) stated that the longer the storage time of sap water, it would reduce the $\mathrm{pH}$ value and increased the solid solution of energy sources for bacteria; consequently, the sap water is damaged. Regard to the nature of sap water which is fast acidic, as well as the location of the palm garden that is far from the place of residence, each palm sugar farmer must have a working hut in his garden, commonly called sakan.

\section{Sap water cooking process}

In the sap water cooking process into molded palm sugar, the most vital part to consider is the quality of the raw materials used, which is the quality of sap water from the flower bunch. Palm sugar farmers in Kekait Village have been known for long of three levels of palm sugar simply based on characteristics that how can be felt, seen, and touched directly. They called it manis sêgêr, sêmêdah, nyêlan. Palm sugar with manis sêgêr quality is sap water with the best quality, has a sweet and fresh taste resembling the taste of coconut water, clear and not sticky even though it has been touched for long time. The medium quality or sêmêdah, the taste of sap begins to sour, somewhat cloudy and slightly sticky even touched for a while. Poor quality is usually called nyêlan; it feels very sour, cloudy and bubbly, and feels sticky when touched by hand. Palm sugar farmers in Kekait Village only use excellent and medium quality of sap water to be cooked into palm sugar.

After ensuring that the sap is of good or moderate quality, the farmer would immediately cook the sap water on the fireplace made of a mixture of clay and sand (sêronggé) in the work hut. Farmers cooked sap water every day in two types of the cooking process, namely halfcooked and fully cooked, depending on the volume of sap resulted in tapping activities. Half-cooked process, if the volume of tapped sap water less than 25 liters, while fully cooked process held if the volume of tapped sap water more than 25 liters. The fully cooked process is held by sugar palm farmers to produce ten molded palm sugar (cupak sugar) at a time, considering the current system of selling palm sugar in Kekait Village, which is sold every ten molded palm sugar. Tamrin et al. (2015) mentioned that palm sugar in South Halmahera is cooked every four days, whereas in the community of Kasepuhan Pasir Eurih the cooked of palm sugar is held once in three days Febriyanti et al. (2017).

It took 3-4 hours in one cooking cycle process. Amin et al. (2010) and Nankean et al. (2013) stated that cooking sugar palm juice traditionally for a long time can maintain the antioxidant component in palm sugar. Starting with the preparation stage, i.e.; clean up the furnace by removing the rest of the previous combustion, washing the large cauldron (vase), stirrer made of palm midrib (penggarung), wood spoon (canting); wash and soak the sugar molders made of bamboo (cupak) using clean water. The next step is filtering the sap water two times. The first filtering is held to clean the sap water from the dirt which included sap water from container by pouring it from a container into a bucket. The second filtering is held by pouring the sap water from the bucket into a large cauldron which aimed to reduce white foam.

Furthermore, the cooking process started by lighting a fire in the furnace. The farmer uses massive fire at the beginning of the palm sugar cooking process. The sap water would be boiled for the first 30 minutes, marked by the appearance of white bubbles. The next minute after the appearance of white bubbles, it would be decreased as a sign that the water content started to decrease due to evaporation and the remaining is sugar liquid. The color of the sap water turned into light brown, entering the 60th minute the color of sap water gets brown. The caramelization signs begin to form (bolo). In the 75th minute, liquid sugar forms brown bubbles, as a second boiling sign (bangkal keduê) occurs; generally, the bubbles produced are higher than the first boil. The farmers added a little grated hazelnut seed (Aleurites moluccana (1.) Willd.) to reduce bubbles so the bubbles could not be spilled of the cauldron. The process of adding hazelnut seed is called nglekongin, from the basic word of nlekong which means hazelnut in Sasak language. According to Istriyani (2011), the oil content in hazelnut seeds is high, which is reach 55$66 \%$ of the weight of the seeds, this allows them to be used as a natural candle so that it could be made the hardening of palm sugar durable. Supposed the hazelnut seed unavailable, the farmers used a little grated coconut (Cocos nucifera L.) instead. For one cooking cycle process, the farmers need to add grated hazelnut or coconut fruit as much as $0.5-1$ teaspoons. Adding too much-grated hazelnut or coconut fruit would actually reduce the quality of palm sugar. 


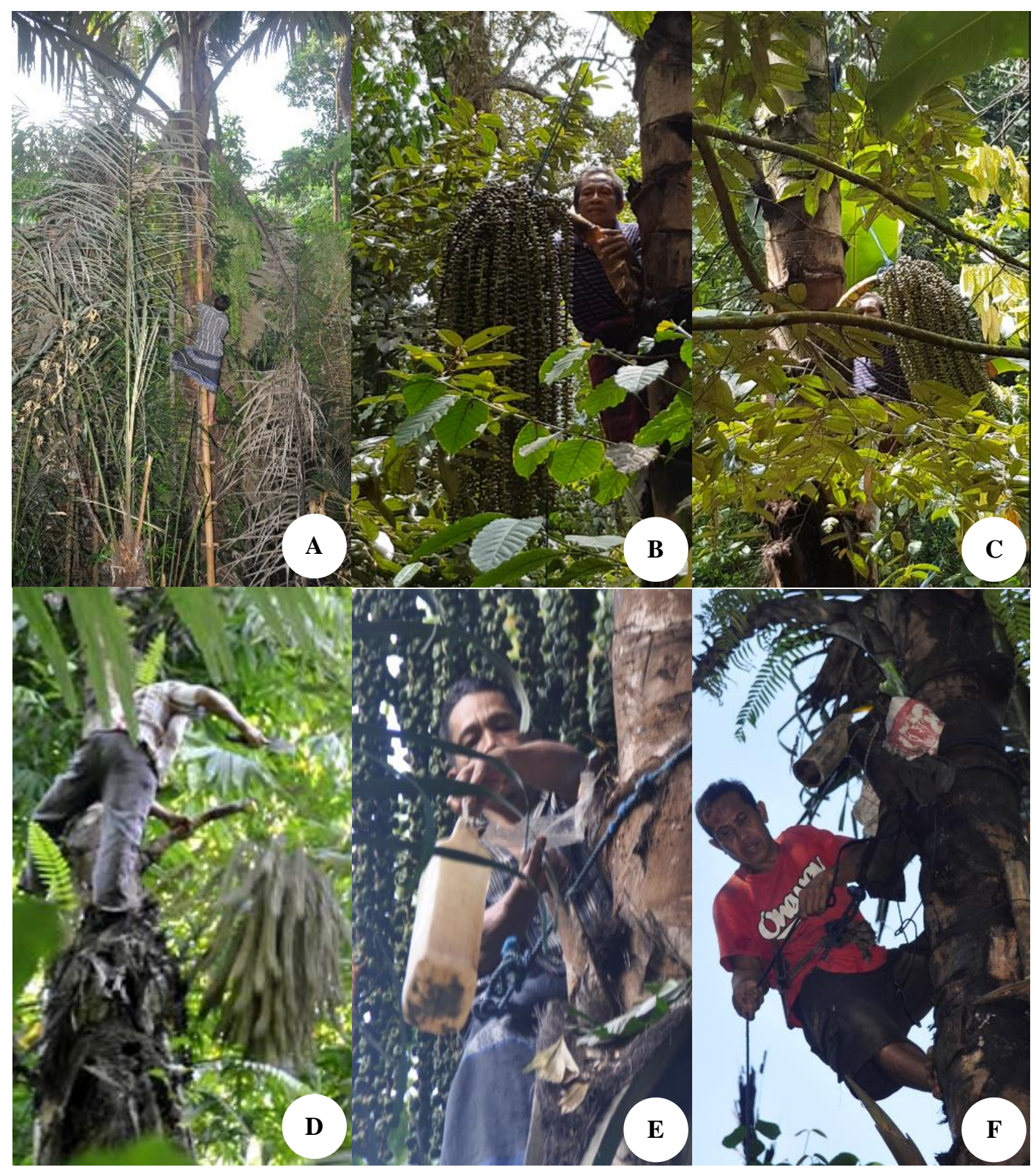

Figure 3. Palm sugar sapping process. A. Installing bamboo ladder, cleaning palm fibers, B. Hitting the flower bunch, C. Shaking the flower bunch, D. Cutting the flower, E. Install and replacing the container

In the 90th minute, the sugar will experience thickening (kêbêq). At this stage, the farmers would conduct a simple test to find out whether palm sugar can later be molded or not. The test is held by taking a little palm sugar and then dipping it into clean water for a moment, then throwing it back to the edge of the cauldron. If the throw produced a "tak" sound, the farmer would be smiling happily, since cooked palm sugar could be molded. On the contrary, where the throw did not produce a sound, it indicated that palm sugar could not be molded. The test also concluded that in a moment the cauldron should be taken off from the furnace and the fireplace should be reduced by pulling a little firewood out of the furnace. The cauldron was taken off from the furnace ( \pm 120 minutes), then the sugar started to be stirred from the center towards the cauldron edge counterclockwise for \pm 60 minutes periodically. The stirring process is conducted to speed up evaporation of heat. For farmers in Kekait Village, which are predominantly Muslim, the direction of the rotation is described as activities surrounding the Ka'bah in a series of Hajj (tawaf) services. They always pray to be able to fulfill one of the Pillars of Islam from the business of palm sugar. Thus, it is not surprising that sugar palm farmers who have been able to fulfill the Hajj are highly respected in Kekait Village.

The stirring stage would be stopped soon after the sugar fibers appear while stirring ( \pm 180 minutes) as a sign of palm sugar ready to be molded. Consecutively, the liquids are poured into bamboo molds (cupak) which have been soaked before. Sugar palm farmers rely on their intuition 
experiences in making molded palm sugar. The bamboo used as molders has a diameter of three adult fingers and three-quarters of the height of an adult's palm. Hence, it is not surprising that palm sugar produced varies significantly in size. In the 195th minutes, the sugar mold was reversed, and a moment later it was removed. Having confirmed the palm sugar cold and hardened, the palm sugar wrapped in dried banana leaves or barrel ( \pm 240 minutes), and palm sugar is ready to put into market. Tamrin et al. (2015) said that palm sugar in South Halmahera was packed using dried banana leaves and then ready to be marketed, while Febriyanti et al. (2017) explained that in the community of Kasepuhan Pasir Eurih besides being packaged using dried banana leaves, palm sugar can be packaged using dried bark leaves, tied and ready to be marketed. According to the farmers, the use of dried banana leaves is not only easily available in the garden and organic but also able to maintain the distinctive aroma of palm sugar. The process of cooking sap into palm sugar can be seen in Figure 4 .

\section{Palm sugar marketing}

Marketing process of palm sugar from farmers to consumers is observed in three marketing channels, which are: zero-level, three-level, and four-level marketing channels, within local to national scale market ranges (Figure 5). The vast number of levels in the marketing channel shows the number of traders between pre to post arrives the palm sugar in the consumers. The zero level channel, or often called direct marketing, is the process of channeling palm sugar from farmers as producers to the consumers without intermediaries. The three-tier channel is a marketing channel with three intermediate traders; village collectors, large collectors in the province, and retailers. While the four-level channel is a marketing channel with four intermediary traders, namely: village collectors, large collectors in the province, large collectors outside the province and retailers. Soekartawi (1989) stated that each marketing institution following its financing capability would carry out marketing functions differently.

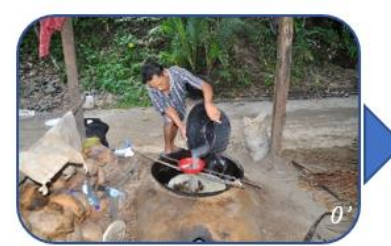

Manis ségér

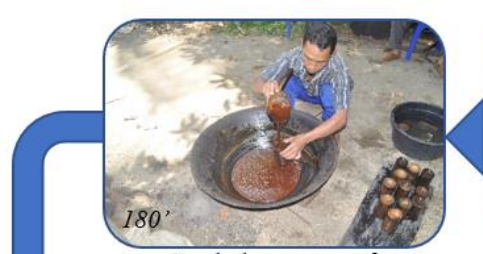

Cetak dengan cupak

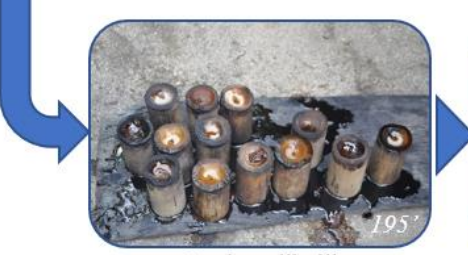

Cetakan dibalik

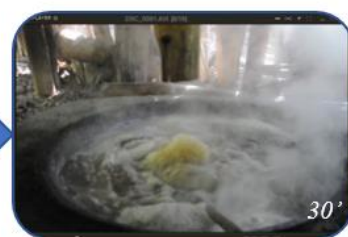

Bangkal pertama

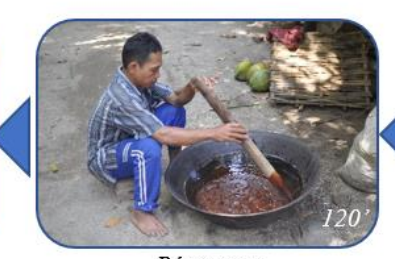

Bégarung

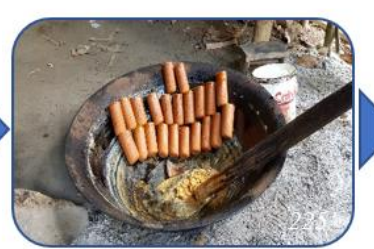

Gula aren

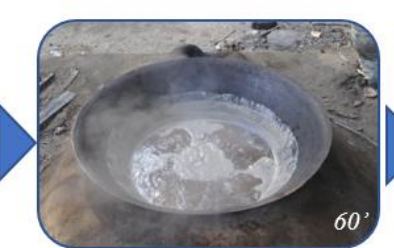

bolo

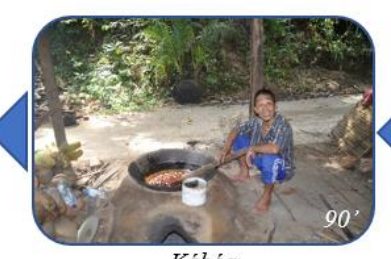

Kébéq

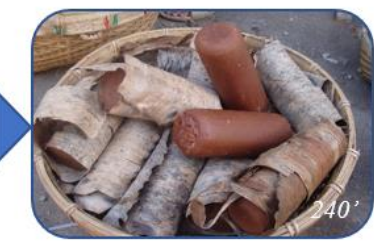

Gula aren

dikemas keraras

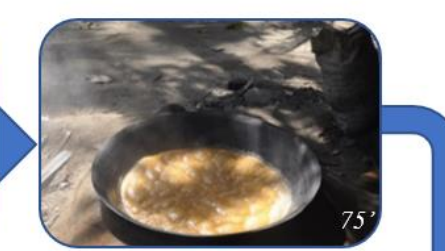

Bangkal kedua

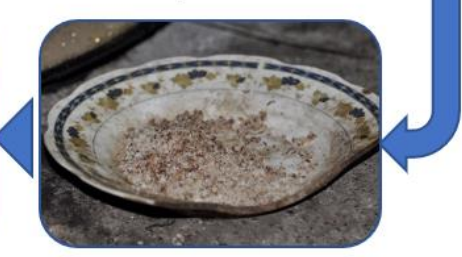

nglekongin

Figure 4 sap water cooking process into palm sugar

$\mathbf{A}$

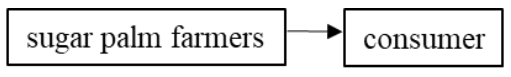

B

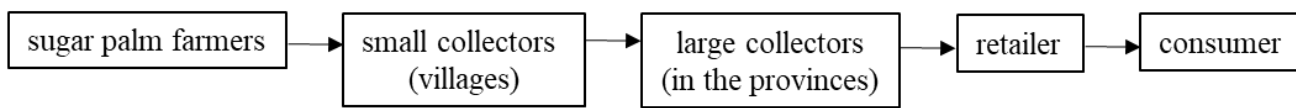

C

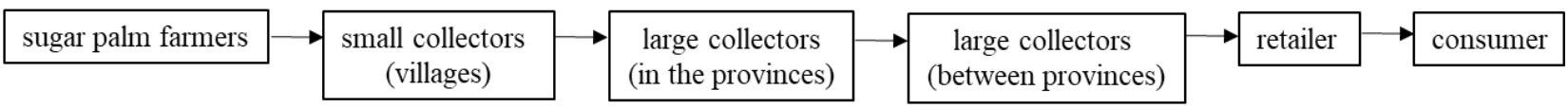

Figure 5. Palm sugar marketing process from farmers to consumers. A. Zero level marketing channel; B. Three-level marketing channel; C. Four-level marketing channel 
Sugar palm farmers in Kekait Village often sold their palm sugar to the village collectors. The same thing was found by Hidayat et al (2016) palm farmers in Capar Village, Brebes District, Central Java prefer to sell palm sugar to collectors so that they can quickly get cash to meet the needs of family members. Based on the field observations it was found 24 village collectors. Village collectors can be divided into two based on their village origin: village collectors who are residents of Kekait Village and outside Kekait Village, each of it 20 and 4 people consecutively. Each village collector has established a bond of trust with 10-15 sugar palm farmers over the years. Bonds are established because the farmers are heavily relying on the sale of palm sugar in order to fulfill their daily needs, while the collectors are willing to pay cash for each palm sugar produced by farmers at that time. For this case, pricing and market information are controlled by village collectors, so farmers could not either determine the price of palm sugar as their wishes or bargained with the collectors. Riyadh (2018) stated that up to now, the supply and value chain or agricultural products in Indonesia have not been efficient. One indicator is the length of the marketing chain of agricultural products from farmers to consumers

In conclusion, the characteristics of sugar palm farmers in the Sasak community were adult men to elderly people, aged 24-63 years old. The skill of how to process sugar palm was passed hereditary from parents or grandparents to their children or grandchildren. Sugar palm farmers in the Sasak community in Kekait Village do not carry out intensive cultivation systems, they relied on nature, both regeneration and distribution. The most widely used parts of the palm tree were the flower bunch $(76.32 \%)$, to be tapped. Processing palm sugar into sugar was still carried out with traditional methods and tools, as well as natural ingredients. Sugar palm farmers in Kekait Village were very dependent on small collectors to sell their sugar products. Farmers were in the weakest position in the marketing channel pattern and do not have a bargaining position to determine the price of palm sugar.

\section{ACKNOWLEDGEMENTS}

The authors would like to express their thanks to the Ministry of Environment and Forestry for the support of scholarships and research, the head of the Kekait Village who giving permission and assistance in this research. Staff of Biodiversity Laboratory, Department of Biology, Faculty of Teacher Training and Education of Mataram University who assisted in the identification of plant species and field surveys, as well as the community and other parties who have helped carry out this research.

\section{REFERENCES}

Abdullah WG, Rianse U, Iswandi RM, Taridala SAA, Widayati W, Rianse IS, Zulfikar, Baka LR, Abdi, Baka WK, Muhidin. 2014.
Potency of natural sweetener: brown sugar. Adv Environ Biol 8 (21): 374-385.

Ain MRF, Yusof YA, Chin NL, Dom ZM. 2014. Storage study of Arenga pinnata juice. Agric Agric Sci Procedia 2: 218-223.

Amin NAM, Mustapha WAW, Maskar MYM, Wai HC. 2010. Antioxidative activities of palm sugar-like flavouring. Open Food J 4: 23-29.

Anderson EN, Pearsall DM, Hunn ES, and Turner JN. 2011. Ethnobiology. John Wiley and Sons, Inc., New Jersey.

Astuti NU, Widyastuti S, Werdiningsih W. 2018. The Effect of Addition of Kurut Wood (Dysoxylum parasiticum) and Storage Duration Time in Cold Temperature Against the Physiochemical and Total Properties of Yeast Palm Sugar [Thesis]. University of Mataram, Mataram. [Indonesian]

Bhat S, Bhandary MJ, Rajana L. 2014. Plant diversity in the homegardens of Karwar, Karnataka, India. Biodiversitas 15 (2): 229-235.

BPS-Statistics Indonesia. 2010. Statistical Yearbook of Indonesia 2010. BPS-Statistics Indonesia, Jakarta. [Indonesian]

Campbell NA, Reece JB, Urry LA, Cain ML, Wasserman SA, Minorsky PV. 2008. Biology. 8th ed. Pearson Benjamin Cummings, San Fransisco, USA

Cotton CM. 1996. Ethnobotany Principles and Applications. John Wiley and Sons, Inc., New York.

Cunningham AB. 2001. Applied Ethnobotany: People, World Plant Use, and Conservation. Earthscan Publication, London.

Djamal M. 2015. Qualitative Research Paradigm. Pustaka Pelajar, Yogyakarta. [Indonesian]

Dransfield J, Uhl NW, Asmussen CB, Baker WJ, Harley MM, Lewis CE. 2014. Genera Palmarum: The Evolution and Classification of Palms. International Palm Society and The L.H. Bailey Hortorium, Cornell University, New York.

Ellen R. 2006. Local knowledge and management of Sago palm (Metroxylon sago Rottboell) diversity in South Central Ceram, Maluku, Eastern Indonesia. J Ethnobiol 26 (2): 258-298.

Febriyanti N, Hikmat A, Zuhud EAM. 2017. The ethnobotany and potential of sugar palm (Arenga pinnata Merr.) on the Kasepuhan Pasir Eurih Community, Sindanglaya Village, Lebak District, Banten. Media Konservasi 22: 171-180. [Indonesian]

Gunawan R, Ramadhan UG, Iskandar J, Partasasmita R. 2018. Local knowledge of utilization and management of sugar palm (Arenga pinnata Merr.) among Cipanggulan People of Karyamukti, Ciajur (West Java, Indonesia). Biodiversitas 19: 93-105.

Hapsari L, Kennedy J, Lestari DA, Masrum A, Lestarini W. 2017. Ethnobotanical survey of bananas (Musaceae) in six districts of East Java, Indonesia. Biodiversitas 18 (1): 160-174.

Hernanto F. 1989. Farming Science. Penebar Swadaya, Jakarta. [Indonesian]

Hidayat RS, Rusman Y, Ramdan M. 2016. Jurnal Ilmiah Mahasiswa Agroinfo Galuh 2 (2): 117-124. [Indonesian]

Hidayati S. 2017. Using Ethnotaxonomy to assess Traditional Knowledge and Language vitality: A case study with the Urang Kanekes (Baduy) of Banten, Indonesia. Indian J Trad Knowl 16 (4): 576-582.

Iskandar J, Iskandar BS, Partasasmita R. 2016. Responses to environmental and socio-economic changes in the Karangwangi traditional agroforestry system, South Cianjur, West Java. Biodivesitas 17: 332-341.

Istriyani YY. 2011. Testing the Quality of Hazelnut Oil by Measuring Optical Rotation Using a Polarimeter. [Thesis]. Diponegoro University, Semarang. [Indonesian]

Kurniawan T, Jayanudin, Kustiningsih I, Firdaus MA. 2018. Palm sap sources, characteristics, and utilization in Indonesia. J Food Nutr Res 6 (9): 590-596.

Lee TC. 2015. Utilization and Conservation of Arenga Species Using the Community Based Natural Resource Management (CBNRM) Approach [Thesis]. Universiti Malaysia, Sarawak. [Malaysian]

Lempang M. 2012. Arenga palm tree and production function. Info Teknis Eboni 9 (1): 37-54. [Indonesian]

Martini E, Roshetko JM, van Noordwijk M, Rahmanulloh A, Mulyoutami E, Joshi L, Budidarsono S. 2012. Sugar palm (Arenga pinnata) for livelihoods and biodiversity conservation in the Orangutan habitat of Batang Toru, North Sumatera, Indonesia. Agrofor 86: 401-417.

Matsumoto DR, Juang LP. 2004. Culture and Psychology. Ed: 3. Cengage Learning, Wadsworth 
Meinarno EA, Widianto B, Halida R. 2011. Humans in Culture and Society: Anthropological and Sociological Views. Salemba Humanika, Jakarta. [Indonesian]

Ministry of Agriculture of the Republic of Indonesia. 2013. Regulation of the Minister of Agriculture Number:133/Permentan/OT.140/12/2013 Good Aren (Arenga pinnata Merr.) Culture Guidelines. Ministry of Agriculture of the Republic of Indonesia, Jakarta. [Indonesian]

Ministry of Health of the Republic of Indonesia. 2009. National Health System. Ministry of Health of the Republic of Indonesia, Jakarta. [Indonesian]

Murtado, Utami ST, Theresia EM. 2016. Aren (Arenga pinnata Merr.) Attractive Investment, not yet Glance. Counseling center. Human Resource Development and Counseling Center, Ministry of Environment and Forestry, Jakarta. [Indonesian]

Nankean P, Meenune M, Roudaut G. 2013. Changes in properties of palm sugar syrup produced by an open pan and a vacuum evaporator during storage. IntL Food Res J 20 (5): 2323-2334.

Parrotta JA, Fui LH, Jinlong L, Ramakrishnan PS, Chang YY. 2009. Traditional forest-related knowledge and sustainable forest management in Asia. For Ecol Manag 257: 1987-1988.

Partasasmita R, Iskandar J, Malone N. 2016. Karangwangi people's (South Cianjur, West Java, Indonesia) local knowledge of species, forest utilization and wildlife conservation. Biodiversitas 17 (1): 154161.

Puspitawati H, Faulkner PE, Sarma M, Herawati T. 2018. Gender relations and subjective family well-being among farmer families: a comparative study between uplands and lowlands areas in West Java Province, Indonesia. J Family Sci 3 (1): 53-72.

Riyadh MI. 2018. Analysis of five important and important food marketing channels in five districts of North Sumatra. Econ Public Pol 9: 161-171.

Soekartawi. 1989. Basic Principles of Management of Agricultural Products. Raja Grafindo Persada, Jakarta. [Indonesian]
Sukenti K, Hakim L, Indriyani S, Purwanto Y, Matthews PJ. 2016. Ethnobotanical study on the local cuisine of the Sasak tribe in Lombok Island, Indonesia. J Ethnic Foods 3: 189-200.

Surya E, Ridhwan M, Armi, Jailani, Samsiar. 2018. Conservation of aren (Arenga pinnata Merr.) in the utilization of sugar palm sap toward improvement of community economy in Padang village, Terayun Gayo Lues Regency. Bionatural 5 (2): 34-45. [Indonesian]

Susilowati SH, Maulana M. 2012. Farm business land size and farmer's welfare: smallholders' existence and agrarian reform urgency. Analisis Kebijakan Pertanian 10 (1): 17-30. [Indonesian]

Tamrin M, Sundawati L, Wijayanto N. 2015. Sugar palm agroforestry management strategies in Bacan Island, South Halmahera District. Min Agric Environ Pol 2: 243-253.

Widayati W, Rianse U, Hanafi H, Abdullah WG. 2018. Empowerment model of aren (Arenga pinnata (Wurmb) Merr.) farmer through their interaction with the environment. Intl J Sci Technol Res 7 (7): 154159

Withaningsih S, Parikesit, Iskandar J, Putri R. 2019. Socio-ecological perspective of local bio-resources based production system of palm sugar and palm flour from aren (Arenga pinnata): Case study of Sukaresmi Village, West Bandung, Indonesia. Biodiversitas 20 (7): 1990-1997.

Yasin N. 2008. Sasak Islamic Marriage Law. UIN-Malang Press, Malang. [Indonesian]

Yuldiati M, Saam Z, Mubarak. 2016. Local Wisdom of the Community in Utilizing Enau Trees in Siberakun Village, Benai District, Kuantan Singingi Regency. Dinamika Lingkungan Indonesia 3 (2): 77-81. [Indonesian]

Zuhud EAM, Siswoyo, E. Sandra, A. Hikmat, E. Adhiyanto. 2014. General Reference Books on Indonesian Medicinal Plants, Volume VIII. Dian Rakyat, Jakarta. [Indonesian] 